\title{
0996. Improventment of method primary cultivation and identification of rat pulmonary microvascular endothelial cells
}

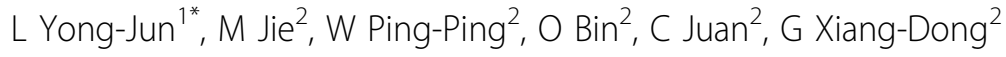 \\ From ESICM LIVES 2014 \\ Barcelona, Spain. 27 September - 1 October 2014
}

\section{Introduction}

Pulmonary microvascular endothelial cell(PMVEC) is a very important tool to study acute respiratory distress syndrome. Several methods for in vitro cultivation of PMVEC have been established, but all the methods damage PMVECs either by use of proteolytic emzymes or by mechanical trauma. This study was to improve the method for primary cultivation of rat pulmonary microvascular endothelial cells and identify the primary cultivated cells.

\section{Objectives}

To improve the method for primary cultivation of rat pulmonary microvascular endothelial cells and identify the primary cultivated cells

\section{Methods}

Pulmonary microvascular endothelial cells were derived from peripheral lung tissue of Sprague-Dawley rats. Primary cultivation method was improved from the procedures of animal selection, lung tissue perfusion, tissue piece pasting, culture medium selection and so on. Inverted microscope was used to observe morphological characteristics of pulmonary microvascular endothelial cells. Immunohistochemical staining for expression of VIII-related antigen and CD31, and observed by fluorescence microscope for binding with lectin from BSI (FITC-BSI binding away) to identified pulmonary microvascular endothelial cells. The cell purity was detected with flow cytometry.

${ }^{1}$ The First Affiliated Hospital, Sun Yat-sen University, Department of SICU, Guangzhou, China

Full list of author information is available at the end of the article

\section{Results}

The PMVECs were exhibited as polygon and presented typical cobblestone-like morphology after fusion to monolayer with contact inhibition. PMVECs turned to be fusiform and presented a swirling or aggregate growth pattern after transfer of culture. Immunohistochemical staining revealed that the expression of CD31 and factor VIII-related antigen was positive. Besides, there were positive findings for FITC-BSI assay. The vitality and growth rate of PMVECs were in good condition. The cell purity was $93.2 \%$ with the improvement method of primary cultivation.

\section{Conclusions}

The improved method for primary cultivation is easy to handle, with favorable repeatability and success rate. PMVECs obtained with this method will display lower contamination, higher purity, faster growth and better status.

\section{Grant acknowledgment}

This study was supported by grant from the National Natural Science Foundation of china (81071536) and Youth Fund of the National Natural Science Foundation of china (81201452).

\section{Authors' details}

${ }^{1}$ The First Affiliated Hospital, Sun Yat-sen University, Department of SICU, Guangzhou, China. ${ }^{2}$ The First Affiliated Hospital, Sun Yat-sen University, Guangzhou, China.

Published: 26 September 2014

\section{References}

1. Magee JC, Stone AE, Oldham KT, et al: Isolation, culture, and characterization of rat lung microvascular endothelial cells. Am J Physiol 1994, 267:L433-41.

2. Chen SF, Fei X, Li SH: A new simple method for isolation of microvascular endothelial cells avoiding both chemical and mechanical injuries. Microvasc Res 1995, 50:119-28.

\section{SpringerOpen ${ }^{\odot}$}

(c) 2014 Yong-Jun et al; licensee Springer. This is an Open Access article distributed under the terms of the Creative Commons Attribution License (http://creativecommons.org/licenses/by/2.0), which permits unrestricted use, distribution, and reproduction in any medium, provided the original work is properly cited. 
3. Epoxygenase-driven angiogenesis in human lung microvascular endothelial cells. Am J Physiol Heart Circ Physiol 2003, 284:H215-24.

doi:10.1186/2197-425X-2-S1-P81

Cite this article as: Yong-Jun et al.: 0996. Improventment of method primary cultivation and identification of rat pulmonary microvascular endothelial cells. Intensive Care Medicine Experimental 2014 2(Suppl 1):P81.

\section{Submit your manuscript to a SpringerOpen ${ }^{\mathcal{O}}$ journal and benefit from:}

- Convenient online submission

- Rigorous peer review

- Immediate publication on acceptance

- Open access: articles freely available online

- High visibility within the field

- Retaining the copyright to your article

Submit your next manuscript at $\gg$ springeropen.com 